\title{
MENINGKATKAN HASIL BELAJAR BAHASA INDONESIA PADA SISWA KELAS VI SD NEGERI 18 KENDARI MELALUI PEMBELAJARAN KOOPERATIF TYPE STAD
}

\author{
Sultan \\ SD Negeri 18 Kendari \\ Email.sultan@gmail.com
}

\begin{abstract}
Abstrak: Tujuan penelitian ini adalah: 1) untuk mengetahui Aktivitas guru dalam Pembelajaran Bahasa Indonesia dengan diterapkannya metode pembelajaran kooperatif model STAD pada siswa Kelas VI SDN 18 Kendari; 2) untuk mengetahui aktivitas siswa dalam pembelajaran Bahasa Indonesia dengan diterapkannya metode pembelajaran kooperatif model STAD siswa kelas VI SDN 18 Kendari; dan 3) untuk mengetahui hasil belajar Bahasa Indonesia yang diajar dengan metode pembelajaran kooperatif model STAD pada siswa kelas VI SDN.18 Kendari. Temuan pada pelaksanaan tindakan pada siklus I,aktivitas siswa dengan menggunakan pembelajaran Kooperatif Model STAD dalam pembelajaran Bahasa Indonesia pertemuan I berada pada skor 53,93 atau kategori cukup dan pertemuan II diperoleh 64,48 atau kategori cukup dan rata-rata keseluruhan diperoleh 59,21 atau kategori cukup. Hasil belajar siswa pada siklus II diperoleh nilai rata-rata prestasi belajar siswa adalah 70,29 dan ketuntasan belajar mencapai $94,11 \%$ atau ada 32 siswa dari 34 siswa sudah tuntas belajar.Hasil tersebut menunjukkan bahwa pada siklus pertama secara klasikal Siswa tuntas belajar,karena siswa yang memperoleh nilai $>70$ hanya sebesar $94,11 \%$ hasil tersebut ketuntasan belajar telah tercapai karena yang mendapat nilai $>70$ lebih besar dari persentase ketuntasan yang dikehendaki.Hal ini disebabkan karena siswa sudah berulang guru menggunakan pembelajaran dengan menggunakan pembelajaran kooperatif model STADBerdasarkan hal tersebut maka dapat dikatakan bahwa model pembelajaran kooperatif model STAD dapat memberikan dampak yang sangat baik terhadap aktivitas guru,siswa dan hasil belajar Bahasa Indonesia siswa pada Kelas VI SDN.18 Kendari.
\end{abstract}

\section{Kata Kunci : Pembelajaran, Kooperatif, Type Stad}

\section{PENDAHULUAN}

Pembelajaran Bahasa Indonesia dewasa ini tidak lagi mengutamakan penyerapan melalui pencapaian informasi, tetapi lebih mengutamakan pada pengembangan kemampuan dan pemprosesan informasi. Untuk itu aktifitas peserta didik perlu ditingkatkan melalui latihan-latihan atau tugas dengan bekerja dalam kelompok kecil dan menjelaskan ide-ide kepada orang lain (Haryono, 2000:24). Pembelajaran Kooperatif lebih menekankan interaksi antar siswa. Dari sini siswa akan melakukan komunikasi aktif dengan sesame temannya.Dengan komunikasi tersebut diharapkan siswa dapat menguasai materi pelajaran dengan mudah karena"siswa lebih mudah memahami penjelasan dari kawannya dibanding penjelasan dari guru,karena taraf pengetahuan serta pemikiran mereka lebih sejalan dan sepadan"(Sulaeman dan Wahyuni 2001:2).

Fenomena yang terjadi pada Kelas VI SDN 18 Kendari diketahui bahwa prestasi belajar Bahasa Indonesia siswa masih tergolong rendah. Selain itu juga siswa kurang tertarik untuk mengikuti pelajaran, siswa merasa bosan belajar yang pada 
akhirnya siswa menjadi malas belajar.inilah salah satu factor yang mengakibatkan rendahnya prestasi belajar. Selain itu juga metode mengajar yangdigunakan oleh guru disekolah hanya menggunakan metode ceramah, Tanya jawab dan pemberian tugas. Berdasarkan hasil ulangan harian pada Semester Genap tahun pelajaran 2018/2019 yang dilakukan Guru Bahasa Indonesia pada Siswa Kelas VI pada SDN.18 Kendari pada mata pelajaran Bahasa Indonesia diperoleh dari 38 siswa yang tuntas belajaranya adalah 8 orang atau $21,05 \%$ dan 30 orang atau $79,95 \%$ yang tidak tuntas berdasarkan KKM yang telah ditentukan oleh sekolah yakni minimal 70 ke atas.

Dengan demikian untuk meningkatkan prestasi belajar siswa tersebut,maka perlu dilakukan Penelitian Tindakan Kelas (PTK) yang berdasarkan pada desain kajian seorang guru agar bisa diterima siswa yang nantinya akan menciptakan suasana pembelajaran yang menyenangkan, mengasyikan dan mencerdaskan. Apabila siswa sudah bisa menerima pembelajaran yang guru sampaikan dengan demikian proses pembelajaran pun akan diikuti dengan baik.Maka dari itu tentunya hasil belajar pun akan meningkat.

\section{Metode Pembelajaran Kooperatif Model STAD} berikut:

Langkah-langkah dalam pembelajaran kooperatif model STAD sebagai

1. Kelompokkan siswa dengan masing-masing kelompok terdiri dari tiga sampai dengan lima orang. Anggota-anggota kelompok dibuat heterogen, meliputi karakteristik kecerdasan, kemampuan, motivasi belajar, jenis kelamin, ataupun latar belakang etnis yang berbeda.

2. Kegiatan pembelajaran dimulai dengan presentase guru dalam menjelaskan pelajaran berupa paparan masalah, pemberian data, pemberian contoh. Tujuan presentase adalah untuk mengenalkan konsep dan mendorong rasa ingin tahu siswa.

3. Pemahaman konsep dilakukan dengan cara siswa diberi tugas-tugas kelompok mereka boleh mengerjakan tugas-tugas tersebut secara serentak atau saling bergantian menanyakan kepada temannya yang lain atau mendiskusikan masalah dalam kelompok atau apa saja untuk menguasai materi pelajaran tersebut.para siswa tidak hanya dituntut untuk mengisi lembar jawaban, tapi juga untuk mempelajari konsepnya. Anggota kelompok diberitahu bahwa mereka dianggap belum selesai mempelajari materi sampai semua anggota kelompok memahami materi pelajaran tersebut.

4. Siswa diberi tes atau kuis individual dan teman sekelompoknya tidak boleh menolong satu sama lai. Tes individual ini bertujuan untuk mengetahui tingkat penguasaan siswa terhadap suatu konsep dengan cara siswa diberikan soal yang dapat diselesaikan dengan cara menerapkan konsep yang dimiliki sebelumnya.

5. Hasil tes dan kuis selanjutkan dibandingkan dengan rata-rata sebelumnya dan poin akan diberikan berdasarkan tingkat keberhasilan siswa mencapai atau melebihi kinerja sebelumnya. Poin ini selanjutnya dijumlahkan untuk membentuk skor kelompok. 
6. Setelah itu guru memberikan penghargaan kepada kelompok yang terbaik prestasinya atau yang telah memenuhi kriteria tertentu. Penghargaan disini dapat berupa hadiah, sertifikat dan lain-lain.

Gagasan utama dibalik model STAD adalah untuk memotivasi para siswa untuk mendorong dan membantu satu sama lain untuk menguasai keterampilanketerampilan yang disajikan oleh guru.Jika para guru mengiginkan agar kelompok mereka memperoleh penghargaan,mereka harus membantu teman sekelompoknya mempelajari materi yang diberikan.Mereka harus mendorong teman mereka untuk melakukan yang terbaik dan menyatakan suatu norma bahwa belajar itu merupakan suatu yang penting,berharga dan menyenangkan.

\section{METODE PENELITIAN}

\section{Tempat, Waktu dan Subjek Penelitian}

Tempat penelitian adalah tempat yang digunakan dalam melakukan penelitian untuk memperoleh data yang diinginkan.Penelitian ini bertempat di SDN.18 Kendari. Waktu penelitian adalah waktu berlangsungnya penelitian atau saat penelitian ini dilangsungkan.Penelitian ini dilaksanakan pada bulan Februari semester Genap Tahun Pelajaran 2018/2019. Subjek penelitian adalah siswa-siswi kelas VI SDN 18 Kendari

\section{Rancangan Penelitian}

Berikutnya adalah perencanaan yang sudah direvisi,tindakan,pengamatan,dan refleksi. Sebelum masuk pada siklus 1 dilakukan tindakan pendahuluan yang berupa identifikasi permasalahan.Siklus spiral dari tahap-tahap penelitian tindakan dapat dilihat pada gambar berikut:

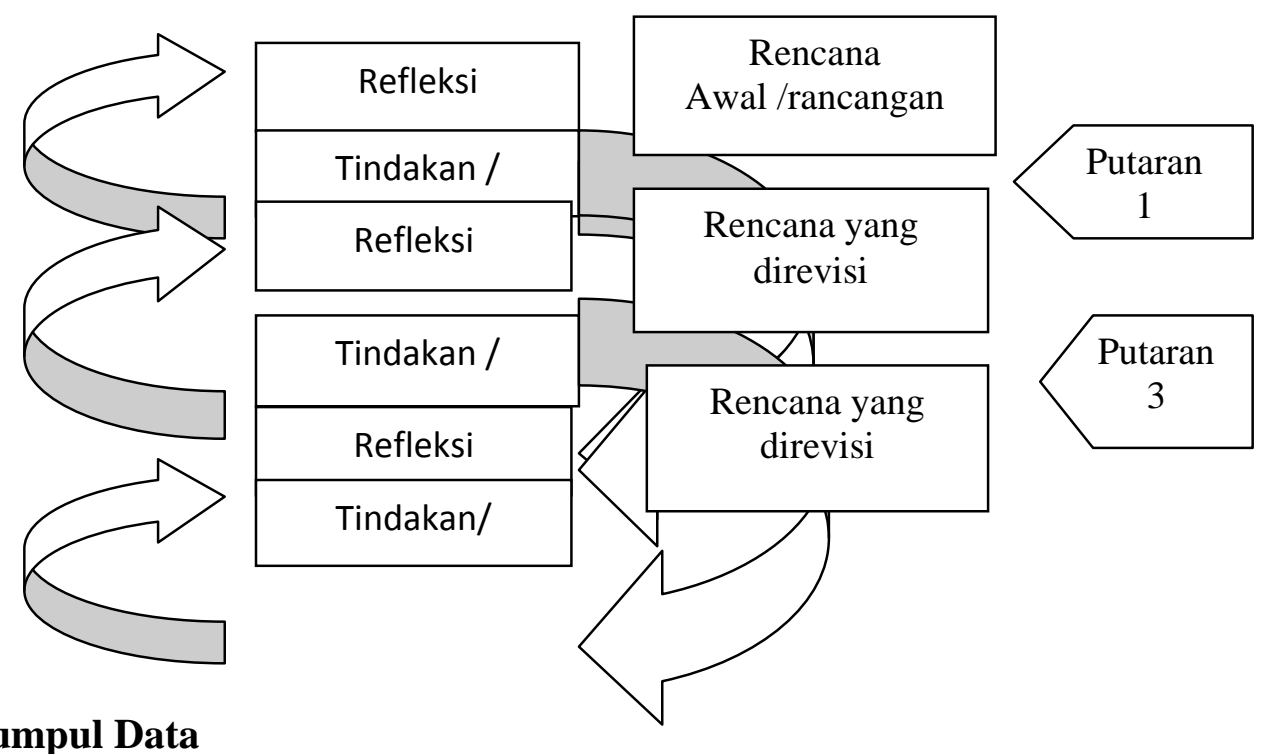

\section{Alat Pengumpul Data}

Alat pengumpul data dalam penelitian ini adalah tes buatan guru yang fungsinya adalah : (1) untuk menentukan seberapa baik siswa telah menguasai bahan pelajaran yang telah diberikan dalam waktu tertentu; (2) untuk menentukan apakah Suatu tujuan telah tercapai; (3) Untuk memperoleh suatu nilai (Arikunto,2002 :19). Sedangkan tujuan dari tes adalah untuk mengetahui ketuntasan belajar siswa secara individual maupun secara klasikal. 


\section{Teknik Analisis Data}

Untuk mengetahui keefektifan suatu metode dalam kegiatan pembelajaran perlu diadakan analisis data. Pada penelitian ini menggutamakan teknik analisis dekriktif kualitatif, yaitu suatu metode penelitian yang bersifat mengambarkan kenyataan atau fakta sesuai dengan data yang diperoleh dengan tujuan untuk mengetahui aktivitas guru,siswa serta berprestasi belajar yang dicapai siswa. Hasil observasi aktifitas guru dan siswa dalam proses pembelajaran kooperatif model STAD tersebut selanjutnya dikonversi dengan Kriteria seperti pada tabel berikut:

\section{Tabel 3.1 Interpretasi Data Persentase Hasil Observasi}

\begin{tabular}{|l|l|l|l|}
\hline No & \multicolumn{1}{|c|}{ Criteria } & \multicolumn{1}{|c|}{ Nilai } & \multicolumn{1}{c|}{ Penafsiran } \\
\hline 1. & Baik sekali & $86-100$ & $\begin{array}{l}\text { Aktivitas guru dan siswa pada saat proses } \\
\text { pembelajaran kooperatif model STAD } \\
\text { baik sekali }\end{array}$ \\
\hline 2. & Baik & $71-85$ & $\begin{array}{l}\text { Aktivitas guru dan siswa pada saat proses } \\
\text { pembelajaran kooperatif model STAD } \\
\text { baik }\end{array}$ \\
\hline 3. & Cukup & $56-70$ & $\begin{array}{l}\text { Aktivitas guru dan siswa pada saat proses } \\
\text { pembelajaran kooperatif model STAD } \\
\text { cukup }\end{array}$ \\
\hline 4. & Kurang & $41-55$ & $\begin{array}{l}\text { Aktivitas guru dan siswa pada saat proses } \\
\text { pembelajaran kooperatif model STAD } \\
\text { kurang }\end{array}$ \\
\hline 5. & Kurang sekali & $<40$ & $\begin{array}{l}\text { Aktivitas guru dan siswa pada saat proses } \\
\text { pembelajaran kooperatif model STAD } \\
\text { kurang sekali }\end{array}$ \\
\hline
\end{tabular}

Adapun acuan dari keberhasilan dalam pelaksanaan tindakan adalah sebagai berikut : 1) Aktifitas siswa berada pada kualifikasi sangat aktif,2) Hasil belajar siswa secara klasikal berada pada kategori baik.

\section{Indikator Kinerja}

Indicator keberhasilan dalam penelitian ini adalah apabila minimal 85\% siswa telah memperoleh skor senilai 70 dan indicator keberhasilan pelaksanaan pembelajaran kooperatif model STAD minimal $80 \%$ scenario pembelajaran telah dilaksanakan.

\section{HASIL PENELITIAN DAN PEMBAHASAN Pembahasan Siklus Hasil Penelitian}

Berdasarkan kekurangan-kekurangan yang ada dan prestasi belajar siswa pada siklus I yang belum memenuhi standar keberhasilan,maka peneliti ini dilanjutkan pada siklus II. Hasil penelitian menunjukkan bahwa kegiatan pembelajaran telah sesuai dengan harapan.Kelemahan-kelemahan pada siklus I telah diatasi pada siklus II sehingga semua siswa telah mencapai standar ketuntasan belajar.

Aktivitas guru dalam pembelajaran Kooperatfi Model STAD dalam pembelajaran Bahasa Indonesia diperoleh pada pertemuan pertama aktivitas guru dengan menggunakan pembelajaran Kooperatif Mode STA $D$ dalam pembelajaran 
dengan skor 65 atau pada kategori cukup dan pada pertemuan kedua diperoleh skor 70 atau kategori baik dan rata-rata keseluruhan diperoleh 67,5 atau kategori cukup.sejanjutnya aktivitas siswa dengan menggunkana Pembelajaran Kooperatif Model STAD dalam pembelajaran Bahasa Indonesia pertemuan I berada pada skor 53,93 atau kategori cukup dan pertemuan II diperoleh 64,48 atau kategori cukup dan rata-rata keseluruhan diperoleh 59,21 atau kategori cukup.

Hasil belajar siswa diperoleh nilai rata-rata persentase belajar Bahasa Indonesia siswa adalah 65,58 siswa yang tuntas belajarnya adalah 20 orang atau $64,67 \%$ dan siswa yang tidak tuntas hasil belajarnya adalah 14 orang atau $35,32 \%$.Hasil tersebut menunjukkan bahwa pada siklus pertama secara klasikal siswa belum tuntas belajar. Aktivitas guru pada siklus II pada pertemuan pertama aktivitas guru dengan menggunakan pembelajaran kooperatif model STAD dalam pembelajaran Bahasa Indonesia diperoleh skor 80 atau kategori baik dan pada pertemuan kedua diperileh skor 90 atau kategori amat baik dan rata-rata

Keseluruhan diperoleh 85 atau kategori baik.Pada pertemuan I berada pada skor 76,98 atau kategori baik dan pertemuan diperoleh $88,89 \%$ atau kategori amat baik dan rata-rata keseluruhan diperoleh 82,14 atau kategori baik. Hasil belajar siswa pada siklus II diperoleh nilai rata-rata prestasi belajar siswa adalah 70,29 dan ketuntasan belajar mencapai $94,11 \%$ atau ada 32 siswa dari 34 siswa sudah tuntas belajar.Hasil tersebut sudah menunjukan bahwa pada siklus pertama secara klasikal siswa tuntas belajar,karena siswa yang memperoleh nilai $>70$ hanya sebesar $94,11 \%$ hasil tersebut ketuntasan belajae siswa telah tercapai karena yang mendapat nilai $>70$ lebih besar dari $85 \%$ sesuai dari persentase ketuntasan yang dikehendaki.Hal ini disebabkan karena siswa sudah berulang guru menggunakan pembelajaran dengan menggunakan pembelajaran kooperatif model STAD.

Berdasarkan hal tersebut maka dapat dikatakan bahwa model pembelajaran kooperatif Model STAD dapat memberikan dampak yang sangat baik terhadap aktivitas guru,siswa dan hasil belajar Bahasa Indonesia siswa pada kelas VI SDN 18 Kendari

\section{PENUTUP}

\section{Kesimpulan}

Berdasarkan hasil pembahasan dapat disimpulkan bahwa melalui pembelajaran Kooperatif Model STAD dapat meningkatkan aktivitas guru dan siswa serta,hasil belajar Bahasa Indonesia siswa kelas VI SDN.18 Kendari

\section{Saran}

Dari hasil penelitian yang diperoleh dan uraian agar proses belajar mengajar Bahasa Indonesia lebih efektif dan lebih memberikan hasil yang optimal bagi siswa, maka disampaikan saran sebagai berikut :

1. Untuk melaksanakan metode pembelajaran kooperatif model STAD memrlukan persiapan yang cukup matang,sehingga guru harus mampu menentukan atau memilih topik yang benar-benar bisa diterapkan dengan metode pembelajaran Kooperatif model STAD dalam proses belajar mengajar sehingga memperoleh hasil yang optimal. 
2. Dalam rangka meningkatkan prestasi belajar siswa guru hendaknya lebih sering melatih siswa dengan berbagai metode pengajaran,walau dalam taraf yang sederhana,dimana siswa nantinya dapat menemukan pengetahuan baru,memperoleh konsep,dan keterampilan,sehingga siswa berhasil dan mampu memecahkan masalah-masalah yang dihadapi.

3. Untuk penelitian yang serupa hendaknya dilakukan perbaikan-perbaikan agar diperoleh hasil yang lebih baik.

\section{Daftar Pustaka}

Ali, Muhammad. 1996. Guru Dlam Proses Belajar Mengajar. Bandung: Sinar Baru Algesindo

Arikunto, Suharsimi. 1993. Manajemen Mengajar Secara Manusiawi. Jakarta: Rineksa Cipta

Arikunto, Suharsimi. 2001. Dasar-dasar Evaluasi Pendidikan. Jakarta: Bumi Aksara

Arikunto, Suharsimi. 2002. Prosedur Penelitian Suatu Pendekatan Praktek. Jakarta: Rineksa Cipta

Azhar, Lalu Muhammad. 1993. Proses Belajar Mengajar Pendidikan. Jakarata: Usaha Nasional.

Daroesa, Bambang. 1989. Dasar dan Konsep Pendidikan Moral Pancasila.

Semarang: Aneka Ilmu.

Djamarah,Syaiful, Bahri. 2002.Strategi Belajar Mengajar. Jakarta: Rineksa Putra.

Djamarah,Syaiful Bahri. 2002.Psikologi Belajar. Rineksa Putra

Sukidin, dkk.2002. Manajemen Penelitian Tindakan Kelas VIII-I. Surabaya : Insane Cendekia

Sukmadinata,Nana Syaodih. 2005. Metode Penelitian Pendidikan.Bandung: PT Remaja Rosdakarya.

Surakhamad,Winarno. 1990. Metode Pengajaran Nasional. Bandung: Jemmars 